\author{
Journal of Economic Info (JEI) \\ ISSN:2313-3376 \\ www.readersinsight.net/jei
}

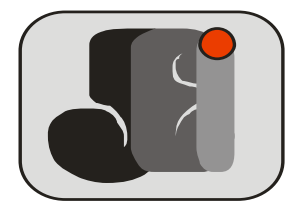

\title{
Analysis of Influence of Mineral Export Policy on Mining Company Value
}

\author{
Harina Paramastri ${ }^{* 1}$, Hesti Wahyuni ${ }^{2}$, Eki Andhika Ratnawardhani ${ }^{3}$ \\ ${ }^{1}$ Politeknik Negeri Malang \\ * Corresponding author: harina.paramastri96@gmail.com
}

\begin{abstract}
This study aims to analyze the influence of mineral export policy through government regulation No.1 Tahun 2014 and No.1 Tahun 2017. Export policy refers to the government regulation that mining companies must carry out mineral processing in Indonesia before export is carried out. This study compares the value of mining companies before, during, and after the regulation is applied which is analyzed using market performance and accounting performance. The mining companies are listed in Indonesia Stock Exchange (IDX) period 2011-2017 that has criteria according to UU No.4 Tahun 2009. This study used purposive sampling which had a population of 49 companies with the sampel of 20 companies. The data were processed by using Friedman and wilcoxon analysis. The results of this study indicate that there is a difference in the value of the company due to the policy applied to decrease the value of the company. The decline in the value of the company occurred after the government imposed government regulation No.1 Tahun 2014, after the government regulation was not implemented the value of the company gradually improved. The result of this study shows that the value of Market Performance that has chi square $6.100(p=0.047)$ is significant. Meanwhile, the result is not siqnificant for the accounting performance based on DER has chi square $1.300(p=0.500)$. The results are significant for ROA which has chi square 14.700 $(p=0.001)$, chi square of ROE is $15.600(p=0,000)$ and chi square of ROI is $14.800(p=0.000)$.
\end{abstract}

Keywords: Mineral Export Policy, Company Value, Mining Company
ARTICLE INFORMATION

Received: 20 April 2019 Revised: 12 May 2019 Accepted: 02 June 2019 DOI: $10.31580 /$ jei.v6i3.922

\section{INTRODUCTION}

Indonesia is one of the countries rich in mineral resources such as nickel, gold, silver, bauxite, copper and tin, but has not been managed optimally to increase state revenues and prosper the Indonesian people (Syahrir, 2017). Therefore the Indonesian government implemented the policies contained in PP No. 1 of 2014 in order to increase mineral added value for the people and the interests of regional development.

Based on the considerations contained in PP No. 23 of 2010 concerning Implementation of Mineral and Coal Mining Business Activities. Mining companies need to purify coal and minerals in the country, in order to increase added value of minerals. The policy on raw mineral exports prohibits a number of positive impacts including the decline in illegal mining practices, encouraging the development of processing industries, increasing economic growth, and reducing the rate of environmental degradation (Tribun Bisnis, 2016).

According to merdeka.com (2014) in the second week of January 2014 the government issued a regulation in which there was an obligation for mining companies to manage their mining products domestically before export. Because the government prohibits mining companies from exporting raw minerals. Moreover large mining companies such as Freeport and Newmont, are looking for loopholes to reject the enactment of the Mineral and Coal Law because the company reap huge profits from the export of raw minerals.

The condition of the government implementing this regulation will have an impact on the performance of the mining industry (Widiastuti, 2017). Because PP No.1 of 2014 was declared ineffective in the mining industry, this regulation was considered impractical in an effort to increase the value added of mining products (Kompas.com, 2014). This policy also caused many companies to carry out production during 20092014 after the issuance of Law No. 4 of 2009 which became the basis for banning the export of raw minerals. Resulting in the price of the metal at a low level (Industri.bisnis.com,2018).

The government is seeking a solution by issuing PP No. 1 of 2017 which provides easy permission for export of raw minerals for all types of minerals (Syahrir, 2017). However, the permit granted this time is a very strict permit, because every six months there will be an evaluation of the progress of the smelter, thus the permit will be revoked if the smelter capacity does not meet the work plan (Investor Daily, 2017). According to the preliminary explanation above, the objectives of this study are: (1) To know the value of the mining company before the enactment of the regulation PP No. 1 of 2014 concerning the ban on mineral exports. (2) To know the value of the mining company during the enactment of the regulation PP No. 1 of 2014 concerning the ban on mineral exports. (3) To know the value of the mining company after the enactment of regulation PP No. 1 of 2017 concerning revocation of the ban on mineral exports (4) To compare the value of mining companies during this period.

\section{LITERATURE REVIEW}

Company value is the market value of debt and equity of the company (Keown, 2010). According to Wihardjo (2014) high companies will provide prosperity for shareholders. According 
to Rachman (2015) the value of the company includes the following values, namely nominal value, intrinsic value, liquidation value, book value and market value. Nominal value is the value listed in the legal articles of association. Market value is the price that occurs from the process of bargaining in the stock market. Book value is the value of the company carried out calculations based on the basic concept of accounting. The value of liquidation is the value of all company assets deducted from the company's liabilities.

Company value can be calculated using market performance and accounting performance. According to Yusuf (2009) market performance is the company's market performance as measured by Tobin's $Q$ developed by James Tobin. Tobin's Q Value Performance Market can be measured using Tobin's $Q$ because it compares stock market prices and asset replacement values (Ardiana, 2012).

Accounting performance is a way to record financial data and compare company performance (Bearley, 2008, p.72). Financial ratio is a technique of comparing elements in financial statements. Types of financial ratios are grouped into 2 types of ratios including leverage ratios and profitability ratios. The leverage ratio is calculated based on data originating from the balance sheet (Syamsuddin, 2002, p.40). This ratio describes the financial risk that the company will receive because of the use of debt in the company's capital structure. Debt Equity Ratio (DER) is one element of calculating the leverage ratio by showing the number of long-term loans given by creditors with the amount of their own capital provided by the owner of the company (Syamsuddin, 2002, p.54).

Profitability Ratio is used by shareholders to find out how profits are generated from investments made and profits generated by the company. According to Syamsuddin (2002) it is used to convince the survival of the company and ensure that the company is in a profitable condition. Here are some ways to calculate company profitability used in this study Return on Assets (ROA) Net income is used to measure profits after deducting interest expense, which makes clear profitability of the company as a function of capital owned (Bearley, 2008, p. 81).

Return on Equity (ROE) a measurement of income for the owner of the company for the capital invested by the owner in the company (Syamsuddin, 2002, p. 64). Return on Investment $(\mathrm{ROI})$ is a ratio calculated by comparing after-tax net income with total assets. According to Syamsuddin (2002) is measuring the ability of companies to generate profits with assets owned by the company.

According to Big Indonesian Dictionary (KBBI, edition V), mining is a process, method, mining activities, through extracting minerals under the sea, underground carried out openly directly related to outside air. Mining management activities in Indonesia use Government Regulation Number 23 of 2010 concerning the Implementation of Mineral and Coal Mining Business Activities to regulate the policy of mining business activities in Indonesia.

The implementation of mineral and / or coal mining business activities prioritizing domestic interests (Article 2, paragraph 1). Based on PP No. 23 of 2010 the supporting government regulations will be produced in mining business activities in Indonesia.

The regulation is PP No. 1 of 2014 made to weigh the increasing use of minerals for the people and increase the value added of minerals through domestic mineral resource refining processing activities. In addition, the government also issued PP No. 12017 due to the implementation of activities to increase the added value of metals through domestic refining has not been fully implemented properly.

Based on the background of the problem and the literature review that has been described, the hypotheses formulated in this research are as follows :
$\mathrm{H} 1$ : There are differences in the value of mining companies before, during, and after implementation of the regulation.

\section{METHODOLOGY}

\section{Population, Sample, Sampling Technique, and Data Collection Methods}

The object of the research was a company in the mining sector listed on the Indonesia Stock Exchange in 2011-2017. Mining is part or all stages of activities in the context of research, processing and exploitation of minerals or coal covering general investigations, exploration, feasibility studies, construction, mining, processing and purification, transportation and sales, and post-mining activities (Law No. 4 of 2009). The population consist of 49 companies. The samples used in this study were purposive sampling, and found 20 companies.

The method of collecting data was documentation. Library studies was carried out by taking a number of literary sources on matters relating to this company.

\section{Research Variable and Variable Operational Definition}

The variables of this research are company value and period of government regulation PP No. 1 of 2014 and PP No. 1 of 2017 . Here is an explanation respectively,

\section{COMPANY VALUE}

According to the variables set out above, the variable definitions used in this study include the value of the company namely the assessment of the performance of the company in carrying out its business activities in fluctuating economic conditions. Company value is an achievement by the company as a form of trust from the community towards the company. Good corporate value can also guarantee the welfare of the owner. Company value can be measured using,

\section{MARKET PERFORMANCE.}

Market performance measured by using Tobin's $Q$ ratio obtained from the stock market value. Tobin's $Q$ formula is as follows:

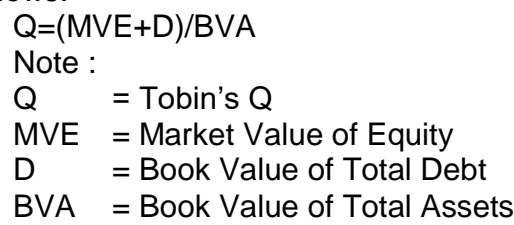

\section{ACCOUNTING PERFORMANCE}

Accounting performance measured by using financial ratios. Company financial ratios are used to compare company performance based on financial data. Financial ratios are grouped into several types, namely :

\section{LEVERAGE RATIO}

Leverage ratio is used to show the company's indicators in fulfilling its financial obligations. The leverage ratio used is Debt Equity Ratio (DER). It shows a long-term loan with its own capital, the following is the calculation formula:

DER $=($ Long Term Debt )/Equity

\section{PROFITABILITY RATIO}

Profitability ratio is used to show the company's ability to earn profits and how profits can be generated by the company. The following are the profitability ratios used in this study 


\section{RETURN ON ASSETS (ROA)}

Net income is used to measure profits against total assets. The following is the calculation formula,

$\mathrm{ROA}=($ Net Profit $) /($ Total Assets $)$

\section{RETURN ON EQUITY (ROE)}

Measurement of income on income for owners of invested capital. The following is the calculation formula used for ROE: $\mathrm{ROE}=($ Earning After Taxes (EAT))/Equity

\section{RETURN ON INVESTMENT (ROI)}

Measuring a company's ability to generate profits from assets owned by the company. Formula for calculating $\mathrm{ROI}$ is:

$\mathrm{ROI}=($ Earning After Taxes $(\mathrm{EAT})) /($ Total Assets $)$

\section{THE PERIOD OF GOVERNMENT REGULATION.}

There are three period observed in this research,

The first period is before the implementation of PP No. 1 of 2014 concerning the mineral and coal export ban, namely in 2009-2013.

The second period is during the of PP No.1 of 2014 concerning the ban on mineral and coal exports, namely in the years 2014-2016.

The third period is after implementation of PP No. 1 of 2014 concerning the ban on mineral and coal exports and was replaced by PP No. 1 of 2017 regarding mineral export licenses, namely in 2017 - now.

\section{DATA ANALYSIS METHOD}

The data analysis method is non statistical analysis parametric using the Wilcoxon Matched Pairs and Friedman test.

\section{RESULTS AND FINDINGS}

\section{Results}

Descriptive statistics are used to support the testing of the characteristics of the data samples used in the study to describe the sample minimum values, maximum values, mean values, and standard deviations for each study variable. The following is the analysis of descriptive statistics:

Table 1. Descriptive Statistics Results

\begin{tabular}{lllll}
\hline Variabel & Minimal & Maximal & Mean & $\begin{array}{l}\text { Std. } \\
\text { Deviation }\end{array}$ \\
\hline Tobin's Q & 0,2487 & 4,7236 & 1,283301 & 0,7616279 \\
DER & $-8,5389$ & 11,2272 & 0,805789 & 2,1521775 \\
ROA & $-0,6012$ & 0,6563 & 0,053246 & 0,1578271 \\
ROE & $-0,6439$ & 1,7994 & 0,056710 & 0,2110545 \\
ROI & $-0,6439$ & 0,4604 & 0,34449 & 0,1288680 \\
\hline
\end{tabular}

Source : Data Processed, 2018

Market performance measured from the value of Tobin's $Q$ which has a value range at $0.2487-4.7236$, an average of 1.283301 , and has a standard deviation value of 0.7616279 . Measured accounting performance of the leverage ratio and profitability ratio.

The leverage ratio is measured using DER which has a value range at $-8.5389-11.2272$, an average of 0.805789 , and has a standard deviation value of 2.1251775 . The profitability ratio is measured using ROA which has a range of values at $0.6012-0.6563$, averaging 0.053246 , and has a standard deviation value of 0.1578271 .
The ratio measured using $\mathrm{ROE}$ which has a range of values at $-0.6439-1.7994$, an average of 0.056710 , and has a standard deviation value of 0.2110545 . The ratio is measured using ROI which has a range of values at $-0.6439-0.4604$, average 0.034449 , and has a standard deviation value of 0.1288680 .

The following are the results of inferential analysis in this study, inferential analysis is an analysis used to explain the results of statistical tests on differences in average periods used in this study simultaneously using the Friedman test analysis and followed by testing the average comparison inter groups of periods using Wilcoxon test.

\section{COMPARISON TEST FOR TOBIN'S $Q$}

Friedman's test results on Tobin's Q's average difference in the three groups of study time periods with chi square of 6.100 were significant $(p<0.05)$. The characteristics of Tobin's $Q$ differences between before and during implementation of the regulation came into effect, 15 mining companies experienced a decline and 5 mining companies experienced an increase when PP No. 1 of 2014 comes into force. Tobin's Q's average is higher in the period before the provisions compared to the period when PP No.1 of 2014. Based on the Wilcoxon test, the differences in these two periods was not significant $(p>0,05)$.

Table 2. Comparison Test of Tobin's Q

\begin{tabular}{|c|c|c|c|c|}
\hline Comparison & & $\mathbf{N}$ & $\mathbf{Z}$ & $\mathbf{P}$ \\
\hline $\begin{array}{l}\text { Tobin's Q (on the time of } \\
\text { implementation)- } \\
\text { Tobins's Q (before the } \\
\text { implementation) }\end{array}$ & $\begin{array}{l}\text { Negative } \\
\text { Positive } \\
\text { No Change } \\
\text { Total }\end{array}$ & $\begin{array}{l}15 \\
5 \\
0 \\
20\end{array}$ & 1,829 & 0,067 \\
\hline $\begin{array}{l}\text { Tobin's Q (after the } \\
\text { implementation) - } \\
\text { Tobin's Q (before the } \\
\text { implementation) }\end{array}$ & $\begin{array}{l}\text { Negative } \\
\text { Positive } \\
\text { No Change } \\
\text { Total }\end{array}$ & $\begin{array}{l}10 \\
10 \\
0 \\
20\end{array}$ & 0,037 & 0,970 \\
\hline $\begin{array}{l}\text { Tobin's Q (after the } \\
\text { implementation) - } \\
\text { Tobin's Q (on the time of } \\
\text { implementation) }\end{array}$ & $\begin{array}{l}\text { Negative } \\
\text { Positive } \\
\text { No Change } \\
\text { Total }\end{array}$ & $\begin{array}{l}6 \\
14 \\
0 \\
20\end{array}$ & 2,016 & 0,044 \\
\hline
\end{tabular}

The characteristics of Tobin's Q's differences between before and after PP No.1 of 2014 apply and were replaced with PP No. 1 of 2017, as many as 10 companies experienced a decline and 10 companies experienced an increase. The Tobin's $Q$ average is higher in the period before the implementation compared to the period after the implementation. Based on the Wilcoxon test, the differences in these two periods was not significant ( $p>0.05)$.

The characteristics of Tobin's $Q$ differences between PP No. 1 of 2014 (when) applies with the replacement of PP No. 1 of 2017 (after), as many as 6 companies experienced a decline and 14 companies experienced an increase. Tobin's $Q$ average is lower in the period of the implementation is compared to the period after the implementation. Based on the Wilcoxon test, the differences in these two periods was significant $(p<0.05)$. In the results of these three comparisons, it was concluded that the imposition of a mineral export ban resulted in a decline in Tobin's Q.

\section{COMPARISON TEST FOR DER}

The Friedman test results on differences in the average DER in the three groups of the study period with chi square of $1,300$ was not significant ( $p>0.05)$. The Characteristics of DER difference between before and during the implementation took effect, as many as 8 companies experienced a decline and 12 
companies experienced an increase. The average DER is higher in the period before the implementation compared to the period of the implementation. Based on the Wilcoxon test, the differences in these two periods was not significant $(p>0.05)$.

Table 3. Comparison Test of DER

\begin{tabular}{lllll}
\hline Comparison & & $\mathbf{N}$ & $\mathbf{Z}$ & $\mathbf{P}$ \\
\hline DER (during the & Negative & 8 & & \\
implementation) - & Positive & 12 & 0,523 & 0,601 \\
DER (before the & No Change & 0 & & \\
implementation) & Total & 20 & & \\
DER (after the & Negative & 8 & & \\
implementation) - & Positive & 12 & \multirow{2}{*}{1,083} & 0,279 \\
DER (before the & No Change & 0 & & \\
implementation) & Total & 20 & & \\
DER (after the & Negative & 9 & & \\
implementation) - & Positive & 11 & 0,336 & 0,737 \\
DER (during the & No Change & 0 & & \\
implementation) & Total & 20 & & \\
\hline${ }^{*}$ Friedman Test :Chi square $=1,300(p=0,522)$ & & \\
Source : Data processd 2018 & & &
\end{tabular}

Source : Data processed,2018

The characteristics of DER differences between before and after the regulation apply, as many as 8 companies experienced a decline and 12 companies experienced an increase. The average DER is lower in the period before the implementation than the period after the implementation. Based on the Wilcoxon test, the differences in these two periods was not significant $(p>0.05)$.

Characteristics of DER differences between the time after the regulation apply, as many as 9 companies experienced a decline and 11 companies experienced an increase. The average DER is lower in the period during the regulation implemented, compared to the period after the implementation of regulation. Based on the Wilcoxon test, the differences in these two periods was not significant $(p<0.05)$. In the results of these three comparisons, it was concluded that the imposition of the mineral export ban had no impact on DER changes.

\section{COMPARISON TEST FOR ROA}

Table 4. Comparison Test of ROA

\begin{tabular}{lllll}
\hline Comparison & & N & Z & P \\
\hline ROA (during the & Negative & 16 & & \\
implementation) - & Positive & 4 & 3,024 & 0,002 \\
ROA (before the & No Change & 0 & & \\
implementation) & Total & 20 & & \\
ROA (after the & Negative & 11 & & \\
implementation) - & Positive & 9 & 0,709 & 0,478 \\
ROA (before the & No Change & 0 & & \\
implementation) & Total & 20 & & \\
ROA (after the & Negative & 2 & & \\
implementation) - & Positive & 18 & 3,547 & 0,000 \\
ROA (during the & No Change & 0 & & \\
implementation) & Total & 20 & & \\
*Friedman Test :Chi square $=14,700 ; \mathrm{p}=0,0001$ & & \\
Source : Data processed, 2018 & & & &
\end{tabular}

The Friedman test results on the difference in average ROA in the three study period groups with chi square of 14,700 was significant $(p<0.05)$. Characteristics of differences in ROA between before and during the regulation took effect, as many as 16 companies experienced a decline and 4 companies experienced an increase. The average ROA is higher in the period before the regulation implementation compared to the period of the regulation impementation. Based on the Wilcoxon test, the differences in these two periods was significant $(p$ $<0.05)$.

Characteristics of differences in ROA between before and after the regulations applied, as many as 11 companies experienced a decline and 9 companies experienced an increase. The average ROA is higher in the period before, compared to the period after the regulation implementation. Based on the Wilcoxon test, the differences in these two periods was not significant ( $p>0.05$ ).

The characteristics of the difference in ROA between the times after the regulations applied, as many as 2 companies experienced a decline and 18 companies experienced an increase. The average ROA is lower in the period during the regulation applied are compared to the period after the regulation implementation. Based on the Wilcoxon test, the differences in these two periods was significant $(p<0.05)$. The results of these three comparisons was concluded that the implementation of the mineral export ban had an impact on reducing $R O A$.

\section{COMPARISON TEST FOR ROE}

Table 5. Friedman Test for ROE

\begin{tabular}{lllll}
\hline Comparison & & N & Z & P \\
\hline ROE (during the & Negative & 16 & 2,949 & 0,003 \\
implementation) - & Positive & 4 & & \\
ROE (before the & No Change & 0 & & \\
implementation) & Total & 20 & & \\
ROE (after the & Negative & 14 & 1,717 & 0,086 \\
implementation) - & Positive & 6 & & \\
ROE (before the & No Change & 0 & & \\
implementation) & Total & 20 & & \\
ROE (after the & Negative & 2 & 3,509 & 0,000 \\
implementation) - & Positive & 18 & & \\
ROE (during the & No Change & 0 & & \\
implementation) & Total & 20 & & \\
*FriedmanTest: Chi square $=15,600 ; p=0,000$ & & \\
Source : Data Processed, 2018 & & &
\end{tabular}

The Friedman test results on the difference in average ROE in the three study period groups with chi square of 15,600 was significant $(p<0.05)$. Characteristics of ROE differences between before and when the regulation took effect, as many as 16 companies experienced a decline and 4 companies experienced an increase. The average ROE is higher in the period before the regulation implementation compared to the period of the implementation. Based on the Wilcoxon test, the differences in these two periods was significant $(p<0.05)$.

Characteristics of ROE differences between before and after the conditions apply, as many as 14 companies experienced a decline and 4 companies experienced an increase. The average ROE is higher in the period before, compared to the period after the regulation implementation. Based on the Wilcoxon test, the differences in these two periods was not significant ( $p>0.05$ ).

The characteristics of the difference in ROE between when and after the conditions apply, as many as 2 companies experienced a decline and 18 companies experienced an increase. Average ROE is lower in the period during the regulation implementation are compared to the period after the regulation implementation. Based on the Wilcoxon test, the differences in these two periods was significant $(p<0.05)$. In the results of these three comparisons, it was concluded that the imposition of the mineral export ban resulted in a decrease in ROE.

\section{COMPARISON TEST FOR ROI}

The Friedman test results on the difference in average ROI in the three groups of the study period with chi square of 14,800 was significant $(p<0.05)$. The characteristics of the difference in ROI between before and during the imlementation of regulation took effect, as many as 16 companies experienced a decline and 4 companies experienced an 
increase. The average $\mathrm{ROI}$ is higher in the period before the imlementation of regulation compared to the period during the imlementation of regulation. Based on the Wilcoxon test, the differences in these two periods was significant $(p<0.05)$.

Table 6. Friedman Test for ROI

\begin{tabular}{|c|c|c|c|c|}
\hline Perbandingan & & $\mathbf{N}$ & $\mathbf{Z}$ & $\mathbf{P}$ \\
\hline $\mathrm{ROI}$ (during the & Negative & 16 & & \\
\hline implementation) - & Positive & 4 & & \\
\hline ROI (before the & No Change & 0 & 2,949 & 0,003 \\
\hline implementation) & Total & 20 & & \\
\hline ROI (after the & Negative & 12 & & \\
\hline implementation) - & Positive & 8 & 1,083 & 0,279 \\
\hline ROI (before the & No Change & 0 & & \\
\hline implementation) & Total & 20 & & \\
\hline ROI (after the & Negative & 2 & & \\
\hline $\begin{array}{l}\text { implementation) - } \\
\text { ROI (during the }\end{array}$ & $\begin{array}{l}\text { Positive } \\
\text { No Change }\end{array}$ & $\begin{array}{l}18 \\
0\end{array}$ & 3,472 & 0,001 \\
\hline implementation) & Total & 20 & & \\
\hline
\end{tabular}

Source : Data processed, 2018

The characteristics of the difference in ROI between before and after the conditions apply, as many as 12 companies experienced a decline and 8 companies experienced an increase. The average $\mathrm{ROI}$ is higher in the period before than the period after the imlementation of regulation. Based on the Wilcoxon test, the differences in these two periods was not significant $(p>0.05)$.

The characteristics of the difference in ROI between the times after the conditions apply, as many as 2 companies experienced a decline and 18 companies experienced an increase. The average $\mathrm{ROI}$ is lower in the period during the imlementation of regulation, compared to the period after the imlementation of regulation. Based on the Wilcoxon test, the differences in these two periods was significant $(p<0.05)$. In the results of these three comparisons, it was concluded that the imposition of a mineral export ban resulted in a decrease in ROI.

\section{Findings}

Based on the results of Tobin's $Q$ test to find out the difference in company value before PP No. 1 of 2014 was implemented, during the implementation of PP No. 1 of 2014 was used to regulate mining export policy regulations, and was replaced by PP No. 12017 gave a significant difference. The results of this study indicated that before PP No.1 of 2014 was issued and at the time the regulation was implemented, gave a non-significant Tobin' $Q$ value.

But when the regulation was replaced by PP No.1 of 2017 the new Tobin's $Q$ value gave a significant value. This finding is different from previous research conducted by Widiastuti (2017) who found that the market performance of mining companies did not decrease due to the resulting ban regulation. According to research conducted by Satriawan (2015) these regulations can have an impact on the Indonesian economy. This will have an impact on reduced state revenues, reduced labor, and the erosion of the trade sector (berandainovasi.com,2015).

In this study it was found that the value of the company based on Tobin's Q's calculation at the time before the regulation with the time the regulation took place there was a difference, that most companies experienced a decrease due to the regulation. However, there was no significant difference between before and after the regulation was implemented because the value of Tobin's $Q$ after the regulation was dismissed began to gradually improve like the value before the regulation was implemented. So when the regulation was replaced with new regulations, there was an increase in the value of Tobin's $Q$.
While based on the difference test results on accounting performance consisted of leverage ratios, namely using DER, and using profitability ratios, namely ROA, ROE, ROI. According to the leverage ratio using DER there were no significant changes due to the regulation thus the DER value before, during, and after the regulation was not affected due to the regulation of regulations applied by the government. According to a study conducted by Kristanto (2018) that the period after the policy on the ban on exports of minerals and metals had a higher level of risk bankruptcy than when the mineral export policy was abolished.

As predicted by one of the sample companies in the study. Based on calculations with profitability ratios there is a consequence that causes the fall in the export price of mining mineral commodities as predicted by PT Vale Indoneisa Tbk (Business Industry, 2018). Thus in this study the change in regulation can affect significant differences in the profitability ratios of mining companies due to the price of commodities sold experiencing price fluctuations.

\section{CONCLUSION}

This research examines the differences in company values due to changes in laws and regulations through testing using Tobin's Q, Debt Equity Ratio (DER), Return on Assets (ROA), Return on Equity (ROE), Return of Investment (ROI) to the companies in the mining sector listed on the Indonesia Stock Exchange (IDX) for the period 2011 - 2017. Tests were carried out to look for differences in company values against the impact of government regulations that apply to mineral and coal mining activities, using non statistical analysis parametric using the Wilcoxon Matched Pairs and Friedman test.

Through the results of the company's value analysis through market performance, the export ban regulations have less favorable impact on the company, while the calculation of company value through accounting performance, according to the results of the leverage ratio calculation does not have an impact on the company but when viewed from the ratio of profitability to export restrictions have less favorable impact to the company.

\section{References:}

Ardiana, Putu Agus. (2012). Variabel - Variabel yang Mempengaruhi Tobin's Q Brokerage House di Indonesia. Jurnal Akuntansi \& Bisnis, 7(2)

Berandainovasi.com. (2015) Larangan Ekspor Mineral Mentah ? Untung atau Rugi ?, dari https://berandainovasi.com/laranganekspor-mineral-mentah-untung-apa-rugi/

Brealey, Richard A., Myers, Stewart C., \& Marcus, Alan J. (2008). Fundamentals of Corporate Finance. Edisi kelima. Jakarta : Penerbit Erlangga. (Original Work published 2007)

Industri.bisnis.com. (2018) Inilah proyeksi Vale Indonesia Terhadap Harga Nikel

http://industri.bisnis.com/read/20180131/44/732870/inilahproyeksi-vale-indonesia-terhadap-harga-nikel.

Investor Daily. (2017). Kuota Ekspor Nikel Sesuai Kapasitas Smelter., darihttp://id.beritasatu.com/energy/kuota-ekspor-nikel-sesuaikapasitas-smelter/167759

Keown, J Arthur., John D., Martin, J., William Petty., David F, Scott Jr. Financial Management: Principles and Applications. Tenth Edition. (2010) Jakarta Barat :PT Indeks. (Orignial work published 2005)

Kompas.com.(2014) Akrobat Larangan Ekspor Mineral Mentah ., dari https://ekonomi.kompas.com/read/2014/01/20/1015555/Akrobat. Larangan.Ekspor.Mineral.Mentah

Kristanto, Aan., Dheasey Amboningtyas., Yulianeu. (2018). Comparative Analysis of Bangkruptcy of Mine and Mineral Mediums Before \& After Application of Export Policy Export of Metal Metals \& Minereals Period 2016. Journal of Management, 4.

Merdeka.com.(2014). 4 Kontroversi seputar larangan ekspor bahan mineral mentah., dari https://www.merdeka.com/uang/4kontroversi-seputar-larangan-ekspor-bahan-mineral-mentah.html 
Peraturan Permerintah Republik Indonesia Pemerintah Nomor 23 Tahun 2010 Tentang Pelaksanaan Kegiatan Usaha Pertambangan Mineral dan Batubara.(2010). Jakarta : Kementrian Hukum dan Hak Asasi Manusia Republik Indonesia.

Peraturan Permerintah Republik Indonesia Nomor 1 Tahun 2014 Tentang Perubahan kedua atas Peraturan Pemerintah Nomor 23 Tahun 2010 Tentang Pelaksanaan Kegiatan Usaha Pertambangan Mineral dan Batubara.(2014). Jakarta : Kementrian Hukum dan Hak Asasi Manusia Republik Indonesia.

Peraturan Permerintah Republik Indonesia Nomor 1 Tahun 2017 Tentang Perubahan keempat atas Peraturan Pemerintah Nomor 23 Tahun 2010 Tentang Pelaksanaan Kegiatan Usaha Pertambangan Mineral dan Batubara.(2017). Jakarta : Kementrian Hukum dan Hak Asasi Manusia Republik Indonesia.

Rachman, N. A. (2015). Faktor-faktor yang Mempengaruhi Nilai Perusahaan pada Perusahaan Manufaktur, Jurnal Nominal.

Satriawan,G. (2015)'Kebijakan Indonesia Dalam Melarang Ekspor Mineral Mentah Tahun 2009- 2014 (Studi Kasus :Larangan Eskpor Mineral Mentah Nikel ke Tiongkok). Jom Fisip, 2(2)

Sugiyono. (2017). Statistika Untuk Penelitian. Bandung : Penerbit Alfabeta

Syahrir,I (2017) ' Kajian Ekonomi \& Keuangan Kebijakan Hilirisasi Mineral : Reformasi Kebijakan untuk Meningkatkan Penerimaan Negara', Kajian Ekeonomi Keuangan 1(1): 42-67.

Syamsuddin, Lukman. (2002). Manajemen Keuangan Perusahaan : Konsep Aplikasi dalam : Perencanaan, Pengawasan, dan Pengambilan Keputusan. Jakarta. PT Raja Grafindo Persada.
Tribun Bisnis (2016). Pemerintah dan DPR Diminta Konsisten Menerapkan Kebijakan Larangan Ekspor Mineral Mentah., dari http://www.tribunnews.com/bisnis/2016/08/01/pemerintah-dandpr-diminta-konsisten-menerapkan-kebijakan-larangan-ekspormineral-mentah.

Tribun Bisnis. (2016). Larangan Ekspor Mineral Mentah Tingkatkan Pertumbuhan Ekonomi., dari http://www.tribunnews.com/bisnis/2016/12/16/larangan-ekspormineral-mentah-tingkatkan-pertumbuhan-ekonomi

Tribun Bisnis. (2017). Relaksasi Ekspor Mineral Cermin Regulasi yang Tidak Konsisten., dari

http://www.tribunnews.com/bisnis/2017/03/03/relaksasi-ekspormineral-cermin-regulasi-yang-tidak-konsisten?page $=2$

Undang - Undang Republik Indonesia Nomor 4 Tahun 2009 Tentang Pertambangan Mineral dan Batubara.(2009). Jakarta : Kementrian Hukum dan Hak Asasi Manusia Republik Indonesia.

Wihardjo, D. S. (2014). Analisis Faktor-Faktor yang Mempengaruhi Nilai Perusahaan (Studi pada Perusahaan Manufaktur yang Terdaftar di BEI Tahun 2009-2011), Jurnal Ekonomi dan Bisnis.

Widiastuti, R. (2017). Dampak Larangan Ekspor Bijih (Raw Material atau Ore) terhadap Nilai Perusahaan, (4), Proceeding 6 th Simposium Nasional Akuntansi Vokasi, pp. 1-9.

Yusuf., Sawitri, Peni. (2009). Modal Intelektual dan Market Performance Perusahaan - Perusahaan yang Terdaftar di Bursa Efek Indonesia. Proceeding PESAT (Psikologi, Ekonomi Sastra, Arstiektur \& Sipil). Gunadarma University. 